\title{
Ethics, intellectual property and commercialization of cultural heritage*
}

\author{
Harriet J. Deacon
}

For citation: Deacon, Harriet J. 2020. Ethics, intellectual property and commercialization of cultural heritage. Pravovedenie 64 (1): 93-111. https://doi.org/10.21638/spbu25.2020.108

\begin{abstract}
The Sámi are an indigenous people residing in Sápmi, a region cutting across northern Scandinavia (Norway, Finland, Sweden) and the Kola Peninsula in Northwest Russia. This article tells the story of a Sámi sun symbol on a seventeen century drum, originally from Swedish Sápmi, that was registered as a trademark by a jewellery company in Norway called "Tana Gull and Sølvsmie AS" in 2009. The mark was invalidated in 2020 because, according to the Norwegian Intellectual Property Office, the registration of a religious symbol was likely to infringe on the rights of the Sámi, whose access to their own cultural and religious symbols should be protected. The basis for the decision was a public policy exception, a provision within trademark law excluding the registration of signs "contrary to morality or public policy", and allowing the law into account public opinion, public interest and human rights. Analysis of this case is used to shape the debate about the role of intellectual property law in addressing the problem of overcommercialization, for example by preventing cultural misappropriation. The authors suggest that the notion of blasphemy or religious offence through banal commercialization should be more broadly formulated in interpretation of the public policy exception in order to take account of cultural misappropriation. They also argue that protecting the public domain by preventing registration of important cultural and religious symbols is not sufficient to address the problem of cultural misappropriation in a commercial context. Positive protection through trademark registrations is just as important as their defensive protection.
\end{abstract}

Keywords: Sámi, Intangible Cultural Heritage, commercialization, cultural misappropriation, trademark, ethics, intellectual property.

\section{Introduction}

The Sámi are an indigenous people residing in Sápmi, a region cutting across northern Scandinavia (Norway, Finland, Sweden) and the Kola Peninsula in Russia ${ }^{1}$. They have experienced significant historical discrimination and persecution, and currently face a number of forms of cultural misappropriation, particularly in the areas of tourism and craft $^{2}$. This paper tells the story of a Sámi sun symbol on a 1693 drum that was registered

Harriet Jane Deacon — PhD, MSc, BA (Hons), Visiting Research Fellow, Coventry University, 1, Priory st., Coventry, CV1 5FB, United Kingdom; harriet@conjunction.me.uk

* The idea of writing a case study arose when the author of this paper was invited, along with Rieks Smeets of the Netherlands, to facilitate a workshop on Sámi intangible cultural heritage at the Sámi Parliament in Karasjok, Norway. I would like to thank Siri Wernberg and Silja Somby from the Parliament for their assistance in providing information about the case. Thanks to Francis Joy, Rieks Smeets, Chiara Bortolotto and Diego Rinallo for their comments. I am responsible for any remaining errors.

1 Solbakk J. T. The Sami People. Karasjok: Sámi Institute, 1990. P. 13-14.

2 Joy F. Sámi Shamanism, Cosmology and Art as Systems of Embedded Knowledge. Doctoral Dissertation. Acta Universitatis Lapponiensis 367. Rovaniemi: The University of Lapland, 2018. Available at: http://lauda.ulapland.fi/handle/10024/63178 (accessed: 28.06.2020).

(c) St. Petersburg State University, 2021 
as a trademark by a jewellery company in Norway called "Tana Gull and Sølvsmie AS" (hereafter Tana Gull) in 2009, and invalidated in 2020. This trademark was (inaccurately) called a "'patent' on the Sámi sun"3. We will use the case to demonstrate how trademark law can play a role in addressing cultural misappropriation and promoting cultural heritage practice and transmission.

In the heritage field, there has been long-standing and widespread concern about potentially adverse impacts of commercialization or marketization of intangible cultural heritage $(\mathrm{ICH})$. Bortolotto has critically interrogated the implied tension between "sacred" heritage and "profane" commerce, and the "embarrassment" that results from bringing these concepts together ${ }^{4}$. Nevertheless, remarkably little attention has been paid to developing a better understanding of the relationship between intangible heritage and the market $^{5}$. The Intergovernmental Committee of the 2003 UNESCO Intangible Heritage Convention, at its 2019 meeting in Bogota, Colombia, has now expressed the need to identify "safeguarding measures and good practices that address the risk of decontextualization and over-commercialization of [intangible heritage] elements". The Committee reminded States Parties that "while recognizing the economic opportunities presented by certain elements of intangible cultural heritage, it is important to prioritize the safeguarding of their social functions and cultural meanings and to clearly distinguish these from the branding or labelling of a product" .

This request comes after over a decade of concern, but very little guidance, from the Committee, or from the UNESCO Secretariat of the Convention, on the relationship between branding or intellectual property protection, (over-)commercialization and safeguarding. The issue is conceptually and politically rather difficult to resolve, and the relationship between $\mathrm{ICH}$ safeguarding, intellectual property protection and commercialization is likely to be complex. General methodologies for tangible heritage management planning also have to be tailored to the circumstances of each case. Case studies are thus needed to inform the design of planning methodologies to maximize the synergies and mitigate the tensions between intellectual property rights protection, $\mathrm{ICH}$ safeguarding and commercialization. Several projects have begun to search for new concepts and tools in this area. The Alpfoodway ${ }^{7}$ and HIPAMS India ${ }^{8}$ projects have demonstrated the importance of community-centered planning to develop heritagesensitive marketing and intellectual property strategies in the European Alps and India respectively.

Branding or labelling of a cultural product, and the registration of marks to do this, is not necessarily incompatible with safeguarding community meanings associated with the underlying heritage practices or traditions. One example of this is the registration of the Sámi Duodji trademark and its use to indicate traditional Sámi handicraft products made by Sámi, which will be discussed below. Intellectual property law, and other legal mecha-

${ }^{3}$ Aslaksen E. A. Har tatt "patent" på den Sámi ske sola // NRK Sápmi. 2018. Available at: https://www. nrk.no/Sápmi/har-tatt-_patent_-pa-den-Sámi ske-sola-1.13902043 (accessed: 28.06.2020). Translated using Google Translate.

${ }^{4}$ Bortolotto $C$. Intangible Cultural Heritage and the Market: The Embarrassment of Heritage Alienability. 2020. Unpublished paper.

5 Lixinski L. Intangible heritage economics and the law: listing, commodification, and market alienation // Safeguarding Intangible Heritage / eds N. Akagawa, L. Smith. London: Routledge, 2018. P. 54-67.

6 Decisions of the Intangible Heritage Convention's Intergovernmental Committee, Bogota, November 2019, DECISION 14.COM 10 // UNESCO. Available at: https://ich.unesco.org/doc/src/LHE-19-14. COM-Decisions-EN.docx (accessed: 28.06.2020).

7 Alpfoodway. Available at: https://www.alpine-space.eu/projects/alpfoodway/en/home (accessed: 28.06.2020).

${ }^{8}$ HIPAMS India. Available at: http://hipamsindia.org/ (accessed: 28.06.2020). 
nisms, can be used in a positive sense, to help communities manage and control the commercialization of their heritage and culture and ensure equitable benefit among them ${ }^{9}$.

Ethical and legal tensions may however arise when the rights of individuals and their communities to take part in cultural life, protected under human rights law or sui generis national provisions, conflicts with exclusive rights granted in the sphere of public law, such as intellectual property rights. Lixinski observes that regulation of the protection of traditional culture and its commercialisation are informed by different logics. The background norms for intellectual property law are found in private law, privileging individualism and party autonomy, whereas heritage law has its origins in public law, privileging public interest and the common good $^{10}$.

From a community perspective, misappropriation of heritage by third parties, for example through the registration and enforcement of trademarks based on cultural or religious symbols, "can dilute the semantic content of cultural expressions as well as their appeal and authenticity" for community members and thus discourage or prevent them practising their culture ${ }^{11}$. Commercial enterprises often use edgy and controversial brands or controversial marks deliberately, to attract consumer attention and eventually increase their market share ${ }^{12}$. Religious symbols may be used deliberately as products or in brands to elicit strong emotional reactions, both positive and negative. For example, in reviewing the marketing success of rosaries as fashion necklaces by Dolce and Gabbana fashion house, Rinallo et al. found that

...the religious and historically established attribute of sacredness contributes a powerfully marketable quality to rosaries, which holds both in terms of their attraction and rebellious possibilities. The appropriation, manipulation, and monetization of sacred meanings by fashion brands such as D\&G open our eyes to emergent new forms of material culture that embody the sometimes turbulent, sometimes-peaceful, and sometimes ecstatic coexistence of the religious and the commercial ${ }^{13}$.

Cultural appropriation may be used as a commercial strategy, not just to create controversy and media coverage, but also to create meaning, where a brand "piggy-backs" on existing cultural value associated with a name, symbol or design. Anemaet suggests that the low threshold for assuming acquired distinctiveness in EU trademark law in fact may create dysfunctional incentives for the registration of cultural symbols as trademarks in Europe. Religious or cultural groups often do not want to, or are unable to, register such marks themselves, or to use them commercially ${ }^{14}$. Anemaet argues that more effective

9 Deacon H., Smeets $R$. Intangible Heritage Safeguarding and Intellectual Property Protection in the context of implementing the UNESCO ICH Convention // Safeguarding Intangible Heritage / eds N. Akagawa, L. Smith. London: Routledge, 2018. P. 36-53.

10 Lixinski L. Commercializing Traditional Culture: Promises and Pitfalls in the Convergence of Intellectual Property Law and Cultural Heritage Law // Annali italiani del diritto d'autore, della cultura e dello spettacolo (AIDA). 2020 (Forthcoming).

11 Mattila T. Needs of the Sámi people for intellectual property protection from the viewpoint of copyright and trademarks - especially with regard to duodji-handicrafts and the Sámi dresses. Finland: Publications of the Ministry of Education and Culture, 2018. No. 40. Available at: http://julkaisut.valtioneuvosto. fi/handle/10024/161206 (accessed: 28.06.2020).

12 Bonadio E. Brands, Morality and Public Policy: Some Reflections on the Ban on Registration of Controversial Marks // Marques Intellectual Property Law Review. 2015. No. 19. P. 43.

13 Rinallo et al. When sacred objects go $B \circledast a(n) d / /$ Consumption and spirituality. 2012. No. 29 (41). P. 37-38.

${ }^{14}$ Liu W. Protection of Religious Signs under Trademark Law: A Perspective of China's Practice // Religions. 2017. No. 8 (11). P. 246-259. 
mechanisms are needed to exclude such signs from registration, thus protecting the public domain and preventing misappropriation ${ }^{15}$.

The "public policy exception" is an existing mechanism in trademark law which has not yet been widely used to address misappropriation of cultural symbols, by which we mean those symbols valued by specific communities because they are linked to their cultural heritage practice or group identity. Although, from an anthropological point of view, religious symbols are a type of cultural symbol, we distinguish in this paper between those symbols that are linked to religious worship (Christian crosses, for example), and those which may be of broader cultural significance to communities. The paper first reviews the use of the public policy exception in trademark law regarding religious or cultural symbols. Second, the case study critically analyses the two main grounds for refusal of the mark: protecting religious sensitivities and the public domain. Finally, it presents some conclusions regarding the role of trademark law in safeguarding and commercialization of cultural heritage.

\section{The public policy exception and cultural misappropriation}

The "public policy exception" allows for refusal of registrations of signs that are "contrary to morality" or public policy ${ }^{16}$. The Paris Convention, for example, allows for refusal of registration when a trademark is considered "contrary to morality or public order and, in particular, of such a nature as to deceive the public"17. The growing literature on the public policy exception has focused on issues such as human rights, access to the public domain, and the refusal of registration to offensive signs ${ }^{18}$. Some of the case law concerns religious symbols, but very little concerns other kinds of culturally important symbols.

Reviewing the registration of trademarks incorporating words from foreign or Indigenous languages in Australia, Richardson et al. have shown that the perspectives of Indigenous and minority communities were often not taken into account assessing the suitability of these trademarks for registration ${ }^{19}$. Indigenous peoples in various countries have experienced misappropriation of their cultural symbols through the registration trademarks. In some cases they have sought to use trademark law, including the public policy excep-

15 Anemaet L. The Public Domain is Under Pressure - Why We Should Not Rely on Empirical Data When Assessing Trademark Distinctiveness // International Review of Intellectual Property and Competition Law. 2016. P. 1-33. Available at: https://ssrn.com/abstract=2749555 (accessed: 28.06.2020). See also: Senftleben M. Public Domain Preservation in EU Trademark Law - A Model for Other Regions? // The Trademark Reporter. 2013. No. 103 (4). P. 775-827. Available at: https://ssrn.com/abstract=2331598 (accessed: 28.06.2020).

16 The Paris Convention for the Protection of Industrial Property, Mar. 20, 1883, 21 U. S. T. 1538, 828 U. N. T. S. 305 [hereafter Paris Convention] art. 6quinquies at B. 3 and Agreement on Trade-Related Aspects of Intellectual Property Rights art. 27 (2), Apr. 15, 1994, Marrakesh Agreement Establishing the World Trade Organization, Annex 1C, 1869 U. N. T. S. 299 [hereafter TRIPS], art. 15 (2). This was transposed into Article 7.1 (f) of the Regulation (EU) 2017/1001 of the European Parliament and of the Council of 14 June 2017 on the European Union trademark.

17 The Paris Convention art. 6quinquies at B. 3.

18 Bonadio E. Brands, Morality and Public Policy; Schovsbo J., Riis T. Public Policy Limitations of Trade Mark Subject Matter - An EU Perspective. Working paper // Social Science Research Network (SSRN). 2018. Available at: https://ssrn.com/abstract=3188013 or http://dx.doi.org/10.2139/ssrn.3188013 (accessed: 28.06.2020); Tavares P. S., Ziemer A. A., Randazza M. J. 2019. Morality and Trademarks: The South American Approach // ip-iurisdictio. 2019. Available at: https://ip-iurisdictio.org/morality-andtrademarks-the-south-american-approach (accessed: 28.06.2020); Ziemer A.A., Tavares P.S., Randazza M. J. Morality and Trademarks: The South American Approach // Suffolk Transnational Law Review. 2017. No. 40 (2). P. 221-278.

19 Richardson M., Thomas J., Klein J. From "Oomoo" to "Oro": nostalgia labels and cultural policy on the Australian trade marks register // The Object and Purpose of Intellectual Property / ed. by S. Frankel. Cheltenham: Edward Elgar Publ., 2019. P. 7-29. 
tion, to address the problem ${ }^{20}$. In the US, after the SLANTS trademark was upheld on the basis of commercial free speech, objections to trademark registration based on offensive use (for example in the REDSKINS case) are now more likely to fail ${ }^{21}$. European courts, by contrast, have tended towards the view that freedom of commercial expression is not constrained by denial of trademark registration because companies can still freely use an unregistered brand or $\operatorname{logo}^{22}$. In addressing the problem of offensive trademarks such as REDSKINS, Phillips suggests that the misappropriation of cultural identity and imagery for use as a trademark can be considered a "dignity taking" proscribed under the Universal Declaration of Human Rights ${ }^{23}$.

In this paper, we are particularly interested to understand to what extent the public policy exception in trademark law in Europe protects against inappropriate use of religious symbols as opposed to significant cultural symbols in general, and whether these protections in trademark law take minority religious or cultural views into account.

Human rights considerations have been particularly influential in European trademark law (and its public policy exception) since the entry into force of the Treaty of Lisbon "placed human rights and fundamental freedoms at the very top of the hierarchy of norms" 24 . These include freedom of religion, freedom of expression (commercial, artistic or political) and prohibition against discrimination in the European Convention on Human Rights, which Norway has ratified ${ }^{25}$. Norway also provides specific protection for Sámi cultural rights and customary law ${ }^{26}$. Article 108 of the Norwegian Constitution tasks the government to assist the "Sámi people to preserve and develop its language, culture and way of life". The International Covenant on Civil and Political Rights (ICCPR), ratified by Norway, protects the rights of minorities to "enjoy their own culture, to profess and practise their own religion, or to use their own language" (art. 27) ${ }^{27}$. Norway, with the other Nordic-Baltic countries, now also strongly supports The United Nations Declaration on the Rights of Indigenous Peoples (UNDRIP) ${ }^{28}$. Article 31.1 of UNDRIP says:

20 Rimmer M. Indigenous Intellectual Property: A Handbook of Contemporary Research. Research Handbooks in Intellectual Property. Cheltenham (UK), Northampton (Mass): Edward Elgar, 2017. A useful if now a bit dated review of the literature can be found in: Pak J. Re-imagining the Wheel: Seeking a Feasible International Regime to Protect Indigenous Cultural Expressions Through Trademark Law // Pacific McGeorge Global Business \& Development Law Journal. 2011. No. 24. P. 381-409.

21 Pro-Football, Inc. v. Blackhorse, 112 F. Supp. 3d 439 (E. D. Va. 2015) was obviated by Matal v. Tam which affirmed that the disparagement clause of 15 U. S. C. S. § 1052(a) was unconstitutional.

22 Geiger C., Pontes L. M. Trade mark registration, public policy, morality and fundamental rights. Centre for International Intellectual Property Studies Research Paper No. 2017-01. 2017. Available at: https://www.ip.mpg.de/en/publications/details/trade-mark-registration-public-policy-morality-and-fundamental-rights.html (accessed 08.07.2021).

23 Phillips V. F. Beyond trademark: the Washington Redskins case and the search for dignity // Chicago-Kent Law Review. 2017. No. 92. P. 1061-1086.

24 Geiger C., Izyumenko E. Shaping Intellectual Property Rights Through Human Rights Adjudication: The Example of the European Court of Human Rights. Centre for International Intellectual Property Studies (CEIPI) Research Paper No. 2020-02. P. 7 // Mitchell Hamline Law Review. 2020. No. 46 (3). Available at: https://ssrn.com/abstract=3613591 or https://open.mitchellhamline.edu/mhlr/vol46/iss3/3 (accessed: 28.06.2020).

25 Review the methodology used by the EUIPO to balance these considerations: Geiger C., Pontes L. M. Trade mark registration...

26 In general, Sámi cultural and political rights are protected more strongly in the three Scandinavian countries than in Russia, where Sámi have not reached the population size required for state recognition as a minority.

27 The United Nations General Assembly. 1966. "International Covenant on Civil and Political Rights". Treaty Series 999 (December): 171. Available at: https://www.ohchr.org/EN/Professionallnterest/Pages/ CCPR.aspx (accessed: 28.06.2020).

28 Nordic-Baltic Statement on the Rights of Indigenous Peoples. 2017. Available at: https://www.norway.no/en/missions/wto-un/nig/statements/hr/hrc/hrc36/nordic-baltic-statement (accessed: 28.06.2020). 
Indigenous peoples have the right to maintain, control, protect and develop their cultural heritage, traditional knowledge and traditional cultural expressions... They also have the right to maintain, control, protect and develop their intellectual property over such cultural heritage, traditional knowledge, and traditional cultural expressions ${ }^{29}$.

While Norway is not a member state of the European Union, Norwegian trademark legislation is harmonized to a large extent with the EU Trademark Directive. European trademark law establishes general principles that govern refusal of registration; these are interpreted in the European Union Intellectual Property Office (EUIPO) guidelines ${ }^{30}$, in decisions by the European Union (EU) and European Economic Area (EEA) courts, including the EUIPO and Human Rights courts (ECtHR) and in national courts.

There is considerable diversity in the interpretation of the public policy exception at the national level: it is "unwritten law" to be interpreted and re-interpreted in each case. While the concepts of morality and public policy are different, they overlap, and in law, do not need to be distinguished as either can be the basis for rejecting a registration ${ }^{31}$. These concepts are acknowledged to be context-specific and subject to changes over time ${ }^{32}$. The idea of public policy (or public order) is an objective criterion. It does not invoke a narrow view of legality, but broader principles and values of government, human rights, international conventions and so on, that are relevant for the functioning of a democratic society and the rule of law ${ }^{33}$. The concept of "accepted principles of morality" is a subjective criterion that aims to protect "the basic moral norms of society" as a whole where the public will feel "insulted, discriminated against or held up to ridicule" rather than acting simply as an arbiter of bad taste for the puritanical ${ }^{34}$. The intention of registration and context of use of the sign are considered when making a decision ${ }^{35}$.

European courts have been somewhat inconsistent in applying the law ${ }^{36}$, although some general trends have emerged ${ }^{37}$. Under the public policy exception, "contrary to morality" provisions can be used to deny registration to signs with either strongly positive or strongly negative connotations. Signs that are determined to be offensive and capable of causing outrage include those that are "pejorative, discriminatory, blasphemous or offensive, or which incite riots", those "associated with terrorist organisations or victims of terror, with the glorification of totalitarian regimes, with criminal acts in nature, or with racial and cultural slurs" 38 . The EUIPO guidelines explain that "the banal use of some signs with a highly positive connotation can also be offensive (e. g. terms with a religious meaning

${ }^{29}$ United Nations Declaration on the Rights of Indigenous Peoples: resolution / adopted by the General Assembly, 2 October 2007, A/RES/61/295 // UN General Assembly. Available at: https://www.refworld. org/docid/471355a82.html (accessed: 28.06.2020).

30 EUIPO trademark guidelines, 2020 edition. Available at: https://guidelines.euipo.europa. eu/1803468/1788542/trade-mark-guidelines/3-accepted-principles-of-morality (accessed: 28.06.2020).

31 EUIPO trademark guidelines, 2020, Chapter 7.3.

32 EUIPO trademark guidelines, 2020, Chapter 7.1. See also: Von Bomhard V., Von Mühlendahl A. Concise European Trade Mark Law. The Netherlands: Wolters Kluwer, Alphen aan den Rijn, 2018.

33 EUIPO trademark guidelines, 2020, Chapter 7.2.1.

34 EUIPO trademark guidelines, 2020, Chapter 7.3. see also OHIM Trademarks and Designs Cancellation Division Decisions 06/07/2015 R 1727/2014-2 "Oval shape".

${ }^{35}$ EUIPO trademark guidelines, 2020, Chapter 7.3; Geiger C., Pontes L. M. Trade mark registration... P. 6.

${ }^{36}$ Reingraber T. Public order and morality as grounds for refusal within trademark law: European and comparative approach. Unpublished Master's thesis. Brussel: Hogeschool-Universiteit, 2012. Available at: https://www.duo.uio.no/bitstream/handle/10852/54532/DINESH-T---Masters-Thesis.pdf (accessed: 28.06.2020). The same seems to be true in Canada, see: Blaiwais L., Miller S. Offensive Trademarks: The Canadian and American Perspectives // Intellectual Property Journal. 2018. No. 30 (2). P. 205-215.

${ }^{37}$ Geiger C., Izyumenko E. Shaping Intellectual Property Rights... P. 7.

38 Geiger C., Pontes L. M. Trade mark registration... P. 11. 
or national symbols with a spiritual and political value... [emphasis added])"39. Although this list of examples is non-exhaustive, it does highlight the way in which the provision has been used more often to protect against religious (rather than cultural) offensiveness, and has focused on "national culture" in the one case where cultural heritage was considered.

Case law provides some examples of decisions on religious symbols, and a few on national symbols where the sign itself is not offensive: in these cases, the thresholds for refusal are high ${ }^{40}$. For example, registration of a symbol of the Christian Latin cross as a trademark of a religious association was denied in 2015 . The decision noted that "religious symbols of very high symbolic value" - such as the cross at issue which it described as "the archetypal and ultimate symbol of Christianity" - "are becoming commonplace as a result of their commercialisation" 41 . The Board of Appeal of the EUIPO took the view that:

signs which severely offend the religious sensitivities of a substantial group of the population are best kept off the register... the very notion that the representation of a Christian cross used for business purposes or for "banal use" and, in particular, for use as a commercial trade mark could cause offence to a section of the relevant public of believers who, inter alia, could regard the religious value of the cross as being compromised ${ }^{42}$.

The Board determined that registration would not only be offensive to the religious sensitivities of Christians, but also to non-Christians whose freedom of belief and cultural diversity would be constrained by the mass commercial distribution or omnipresence of commercial religious signs. Granting the registration would have infringed the freedom of other religious groups to use the sign, which is more of a public policy argument ${ }^{43}$.

In other cases, religious symbols, including crosses, have been registered as trademarks ${ }^{44}$. In a 2015 case involving a mark similar to (but not exactly the same as) a Sufi religious symbol, the OHIM Cancellation Division allowed the registration because it was not provided with evidence of the "utmost spiritual importance [of the symbol] in at least a part of the Community", or offence caused specifically by use of the registered mark. The decision states that it would be an "unreasonably great restriction to exclude from registration all the words and images which have a connection with religion, unless the mark is blasphemous" 45 . Evidence of a high degree of symbolic value, and the offence that would result from registration of the mark, is thus required in order to refuse registration to religious symbols that are strongly positive, and not in themselves offensive.

Symbols of cultural heritage have also been denied trademark registration, but there is only one recent case where this has been the grounds for refusal, and again the bar is set very high. In 2017, the EFTA Court found that artworks by Gustav Vigeland owned by the Municipality of Oslo should be denied trademark registration once they lost protec-

39 EUIPO Trademark guidelines 2020, Chapter 7.3.

40 EUIPO Boards of Appeal Decision of 10/09/2015, R 510/2013-1, Representation d'une Croix (fig.), para 12 and 58 (Geiger C., Pontes L. M. Trade mark registration... P. 9). In the UK, the registration of the mark "Jesus" for clothing was denied (Bonadio E. Brands, Morality and Public Policy. P. 46). UK judgment (IPO), No. O-210-03, IR No. 776 058, JESUS, para. 17-19. ECHR, Metropolitan Church of Bessarabia and Others v. Moldova, ECHR 2001-XII, para. 114 et seq. In regard to national symbols with a spiritual and political value, see 17/09/2012, R 2613/2011-2, ATATURK, § 31.

41 Representation of a cross (fig.).

42 Representation of a cross (fig.), para. 49, 61. See also 06/07/2006, R 495/2005-G, SCREW YOU, para. 20.

43 Representation of a cross (fig.), para. 54.

44 Community trademarks for religious goods or services (No. 8402273, No. 8919433 and No. 7232622).

45 Oval shape. 
tion under copyright law. The court felt that "accepted principles of morality are violated when particular works of authorship that are part of a nation's cultural heritage are misappropriated or desecrated by applicants seeking to register these works as trademarks", thereby posing a "genuine and sufficiently serious threat to a fundamental interest of society" because they would not be available to all. Since the court did not want to establish a precedent for protecting all public domain artworks, for Vigeland's artworks to be denied trademark registration, they had to reach a high threshold value to the relevant public of an EEA State (i. e. Norway). The artworks had to "enjoy a particular status as prominent parts of a nation's cultural heritage" 46 . The public policy exception is used only "in exceptional circumstances" and where the "registration is regarded as a genuine and serious threat to certain fundamental values, or where the need to safeguard the public domain, itself, is considered a fundamental interest of society" 47 .

To what extent can the public policy exception thus be used to protect against trademark registration of signs which have a positive connotation (i. e. they are not racist insults) ${ }^{48}$ whose registration would primarily offend minority groups and indigenous peoples? The impact of trademark registration is generally considered across all relevant social strata, including minorities and ethnic groups ${ }^{49}$. The public who are considered when the IPO or the court determines the level of likely outrage that would be caused by registration of the mark is what is known as the "relevant public" in trademark law. This is "the reasonable consumer with average sensitivity and tolerance thresholds" (i. e. not a small group with extreme views ${ }^{50}$. It would include not just the likely consumers of the goods or services, but also those (such as a religious minority) who might be offended by the registration of the mark even if they were not the intended consumers. It might also include those of other faiths and cultural affiliations, who may not be offended ${ }^{51}$. This is in line with the position taken by the United Nations Human Rights Committee that "limitations of rights for the purpose of protecting morals must be based on principles not deriving exclusively from a single tradition"52. The European Court of Human Rights also seeks to balance protecting the feelings of religious people against commercial freedom of expression ${ }^{53}$.

In conclusion, the public policy exception has been used more frequently for protecting "religious" rather than more broadly "cultural" symbols, and for protecting national rather than minority cultural symbols. Religious symbols with a positive connotation need to be of "utmost spiritual importance", and culturally significant symbols such as the Vigeland artworks, had national value. As European trademark law becomes more sensitive to fundamental rights considerations such as freedom of speech, grounds of "offensiveness" may become less persuasive in courts seeking to uphold principles of "pluralism, tolerance and broadmindedness" 54 . It may be necessary to invoke the "fundamental in-

46 EFTA Court, Case E-5/16, Municipality of Oslo "Vigeland", paras. 92-93, 95. See: Geiger C., Pontes L. M. Trade mark registration... P. 11-12.

47 "Vigeland", para. 8.

48 See examples of racist insults whose registration has been refused in EUIPO trademark guidelines, 2020, Chapter 7.4.

49 Geiger C., Pontes L. M. Trade mark registration... P. 9.

50 EUIPO trademark guidelines 2020, Chapter 7.3. See also: Von Bomhard V., Von Mühlendahl A. Concise European Trade Mark Law.

51 Representation of a cross (fig.), para. 32.

52 CtHR, Sekmadienis Ltd. v. Lithuania, No. 69317/14, Jan. 30, 2018, para. 81.

53 For example, Lithuanian advertisements for clothing using the captions "Jesus, what trousers!" and "Dear Mary, what a dress!" were allowed by the ECtHR, even though the religious community objected, and they had been found at the national level to be "contrary to public order and public morals", see Sekmadienis, above.

54 Geiger C., Izyumenko E. Shaping Intellectual Property Rights... P. 7. 
terest of society" or human rights law, including provisions on discrimination, to support refusal of trademark registration of minority and indigenous religious and cultural symbols that have a positive connotation.

Some challenges remain. First, if the model of offensiveness in trademark law is modelled on ideas of moral concerns, and religious blasphemy or banalization of sacred symbols, it might be easier to protect against misappropriation of specifically "religious" than more generally "cultural" symbols. Second, refusal of trademark registration does not necessarily protect against continued misuse or offensive use by third parties, because keeping important religious and cultural symbols in the public domain encourages free use, but does not give minority communities any control over the use of their cultural symbols by others (see UNDRIP art. 31). These challenges will be discussed in relation to the Sámi sun symbol trademark case.

\section{The Sámi sun symbol trademark case. A "patent" on the Sámi sun}

This case study will be used to illustrate the use of the public policy exception to address cultural misappropriation, and some of the challenges and opportunities mentioned above.

The Sámi have traditionally worn silver jewellery with their traditional dress (Gákti), often made outside of Sápmi and sold by itinerant traders. In 2018, a story broke in the Norwegian media that a (non-Sámi owned) jewellery firm, Tana Gull, had taken out "a "patent" on the Sámi sun"55. After registering and abandoning a few prior marks using the same sign, based on a Sámi sun symbol, the company had registered a trademark in 200956, and had started enforcing it (Figure 1).

The sun in question was a symbol that had been depicted on a historical Sámi drum of the bowl type originally from the Lule Lappmark region

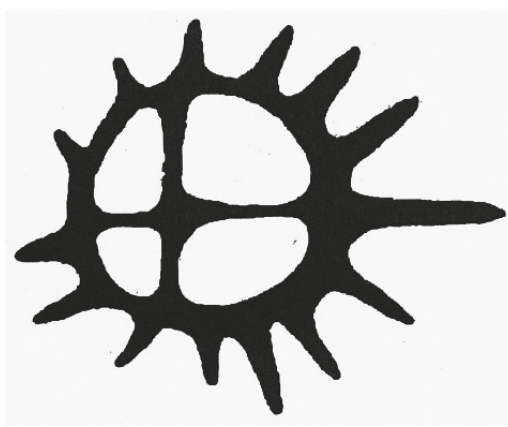

Figure 1. The Tana Gull logo registered in 2009

Photo source: Norwegian trademark register. Available at: https://search. patentstyret.no/Trademark/200815738

(accessed: 28.06.2020) in Sweden ${ }^{57}$. Now kept in the Grassi Museum für Völkerkunde, Leipzig, the drum had been taken from a Sámi shaman in $1693^{58}$.

In the $17^{\text {th }}$ and $18^{\text {th }}$ centuries, the Sámi had been persecuted by Christian missionaries and local authorities as part of an attempt by the Swedish king to control resources

55 Aslaksen E. A. Har tatt "patent" på den Sámi ske sola.

56 Norwegian IPO website, trademark registration and documents for Tana Gull trademark (registration No. 251306) can be found at: https://search.patentstyret.no/Trademark/200815738 (accessed: 28.06.2020).

57 A Swedish ethnographer called Ernst Manker (1893-1972), who worked at the Museum of Ethnography in Stockholm in the middle of the twentieth century, documented many of the drums in museum collections. The drum in question is No. 65 in: Manker E. M. Die Lappische Zaubertrommel: Eeine Ethnologische Monographie. Vol. 1: Die Trommel als Denkmal Materieller Kultur (Acta Lapponica 1). Stockholm: Thule, 1938; Vol. 2: Die Trommel als Urkunde Geistigen Lebens (Acta Lapponica 6). Stockholm: Gebers, 1950.

58 The persecution of the shamans fuelled a thriving trade in Sámi artefacts by the nineteenth century, involving missionaries, anthropologists and museums or private collectors. Sámi drums were dispersed around the world and many were acquired by European museums, see: https://old.no/Sámidrum/locations.html (accessed: 28.06.2020); Joy F. Sámi Shamanism, Cosmology and Art as Systems of Embedded Knowledge; Silvén E. Contested Sámi Heritage: Drums and sieidis on the Move, in National Museums and the Negotiation of Difficult Pasts // EuNaMus Report. No. 8 / eds D. Poulot, J. M. L. Guiral, F. Bodenstein. Linköping: Linköping University Electronic Press, 2012. P. 173-186. 


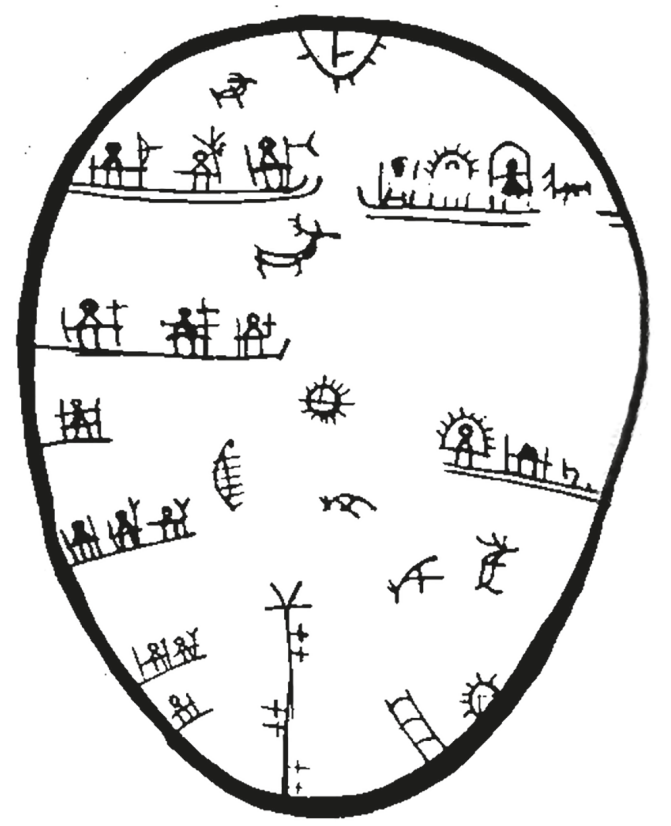

Figure 2. The 1693 drum on which the sun symbol was originally depicted

Photo source: Manker E. M. Die Lappische Zaubertrommel: Eeine Ethnologische Monographie. Vol. 2: Die Trommel als Urkunde Geistigen Lebens (Acta Lapponica 6). Stockholm:

Gebers, 1950. P. 417

and collect taxes in the area. Sami cultural practices, such as the use of drums by shamans, were denigrated, prohibited and driven underground. Use of the drum for "sorcery" was punishable by death ${ }^{59}$.

At the time, drums were central to shamanic rituals. Sámi shamans, called noaidi in Northern Sámi, used the drum mainly for divination in relation to hunting, fishing and trapping, as well as for trance and out-of-body travel, prophecy and fortune-telling ${ }^{60}$. Each shaman made their own drum, or inherited it through the family, so symbols drawn onto the reindeer skin-covered surface were somewhat individualized. Drums could represent the constellations, a geographical map, and be a spiritual map at the same time, depending on their orientation ${ }^{61}$. Sun worship was an important part of Sámi religious beliefs, especially amongst the Southern Sámi. Symbols of the sun thus usually have a central place on the drums ${ }^{62}$, although the sun is depicted in different ways. Some south-Sámi drums depicted a star map outlining the astral mythology of the night sky featuring animal constellations. On the painted drum surfaces the cosmos was divided into two to five realms

59 Joy F. Sámi Shamanism, Cosmology and Art as Systems of Embedded Knowledge. P. 223.

60 Ibid.; Solbakk J. T. Sámisk mytologi og folkemedisin // Tradisjonell kunnskap og opphavsrett / ed. by J. T. Solbakk. Karasjok: Callidlagadus and Sámi kopiia (online), 2007. P. 22, 24-25. Available at: http:// www.Sámikopiija.org/web/index.php?sladja=7\&giella1=nor (accessed: 28.06.2020).

61 Sommarström B. The Saami Shaman's drum and the star horizons // Scripta Instituti Donneriani Aboensis. 1991. No. 14. P. 136-168.

62 Solbakk J. T. Sámisk mytologi og folkemedisin. P. 22, 24-25. 
and many of these depicted a Sun at the centre. The drum in question (Figure 2) depicts 6 levels, which makes it unique ${ }^{63}$.

Starting in the seventeenth century, missionaries and local authorities represented the drums as symbols of paganism. While some Sámi abandoned their religious practices altogether and converted to Christianity, others hid the drums away and used them in secret well into the $20^{\text {th }}$ century. Practitioners such as Peter Armstrand, a Swedish Sámi drum maker and healer, have revitalized Sámi spiritual practices today and created contemporary drums inspired by historical designs ${ }^{64}$. A book published in 1988 by the Sámi artist Nils-Aslak Valkeapää, which won a major literary prize in Norway, revived community interest in the sun symbol and its meaning to the Sámi. This may have also inspired the trademark registrations by Tana Gull65.

In 2018, the media reported that Tana Gull had started enforcing their trademark rights against Sámi craftspeople by sending legal letters demanding they stop using the sign as a decorative element in their work. The owner of the company was quoted as saying "We do not own the sun, but we do own this sun"66. In May 2019, Anastasia Johansen, whose designs had been inspired by Valkeapää's book, was one of the Sámi craftspeople who received a letter from Tana Gull. She said she found the restrictions on using the sun symbol in her products "incomprehensible". Social media exploded with opposition and debate on the issue and a boycott of the jewellery company was proposed in support of Johans$e^{67}$. The jewellery company fought back against the bad press they were getting ${ }^{68}$. By the end of 2019, another of the Sámi crafts businesses using the symbol, Alveskogen Design, had requested an administrative review of the trademark by the Norwegian Patentstyret or Intellectual Property Office (IPO).

In early 2020, the IPO found that the Tana Gull mark was based on a symbol of the Sámi sun god Beaivi and at the time of registration it was a religious symbol that was known to the Sámi, as evidenced by Valkeapää's book ${ }^{69}$. They thus invalidated the mark on the basis of the public policy exception in trademark law. There were two main grounds for this decision. First, the registration of a religious symbol was "liable to provoke indignation" among the Sámi, which was considered equivalent to being "contrary to morality"70. Second, the IPO found that given the history of oppression, it was particularly important to ensure Sámi had access to their few remaining cultural and religious symbols, which was denied by giving Tana Gull a monopoly on use of the sign in trade. The IPO referenced protections given to Sámi culture under the Norwegian Constitution (section 108) and art.27 of

63 Joy F. The Importance of the Sun Symbol in the Restoration of Sámi Spiritual Traditions and Healing Practice // Religions. 2020. No. 11 (6). P. 270-292.

64 Ibid.

65 Patentstyrets avgjørelse av 22. januar 2020 - Administrativ overprøving (hereafter Administrative review) // Norwegian IPO.2020. Available at: https://search.patentstyret.no/Home/OpenFile?docnr=090 167088194fc6d\&appid=32-02\&fileType=pdf (accessed: 28.06.2020). Translated using Google Translate.

66 Aslaksen E. A. Har tatt "patent" på den Sámi ske sola.

67 Social media cooking for sun patents // Newsbeezer. 2019. Available at: https://newsbeezer. com/norwayeng/social-media-cooking-for-sun-patents-threatened-with-boycott-nrk-Sápmi (accessed: 28.06.2020).

68 NRK beklager manglende tilsvarsrett og feil sitat i oppslag om solmotiv // NRK.2019. Available at: https://www.nrk.no/Sápmi/nrk-beklager-manglende-tilsvarsrett-og-feil-sitat-i-oppslag-om-solmotiv-1.14575743 (accessed: 28.06.2020). Translated using Google Translate.

69 Norwegian IPO. Administrative Review. 22 January 2020.

70 In 2009, when the Tana Gull mark was registered, the 1961 Trademark Act governed trademark registrations. Section 14.1.1 of this Act says that a trademark cannot be registered if it "is contrary to law or public order or is liable to provoke indignation" (Google translation). In the 2010 Trademark Act, the word "indignation" is replaced by "contrary to morality". The IPO review stated that this change in terminology was not intended to entail some change in reality, and they therefore viewed the terms in the same light. Norwegian IPO, Administrative Review, 22 January 2020. 
the ICCPR. The registration of the mark was thus invalidated, and costs were awarded to Alveskogen Design. Today, the jewellery company still uses the mark as their $\operatorname{logo}^{71}$, but it cannot prevent others (including Sámi craftspeople) from using it in the course of trade. The symbol is thus now again available for anyone to use.

Since trademark law is territorial, invalidation of the mark in Norway does not of course invalidate registrations elsewhere. In fact, as Mattila has noted, Tana Gull registered the same mark in Finland in 2015, and this registration is still in force ${ }^{72}$. A regional approach, discussed below, is thus needed to address the problem.

The grounds for the administrative decision in this case will now be discussed in further detail, illustrating the importance of taking into account the burden of the past, the history of a community and their religious or cultural practice. The paper will discuss this question in regard to the focus on protecting religious rather than broader cultural symbols, and the limitations of protecting public domain access in preventing cultural misappropriation.

\section{The focus on religion}

As we discussed above, perhaps because of the powerful idea of blasphemy as a measure of moral outrage, there are more precedents in trademark law to protect against religious offensiveness than cultural misappropriation more generally. Offence to religious sensitivities through "profane" commercialization (a kind of "blasphemy") was used as one of the arguments to refuse registration of the sun symbol, but this may not be aligned with how the Sámi today perceive the significance of such a symbol.

In the administrative review, the Norwegian IPO noted the religious nature of the symbol, citing its relationship to the Sámi sun god Beaivi. The use of the sign on Valkeapää's book, a widely-known collection of poems about the sun god published in $1988^{73}$ was used as evidence that the Tana Gull trademark sign would in 2009 have been recognized by the Sámi as a symbol of the Sámi sun god Beaivi. The IPO decision cites the "Representation of a cross" case, discussed above, to suggest that religious symbols of such significance should be kept off the register: "banal" commercialization of an important religious symbol would automatically be a ground of offence ${ }^{74}$. No specific evidence was presented, however, to show that a significant proportion of the Sámi would have been offended by such "banal" commercialization in 2009 on religious grounds ${ }^{75}$. Commercial use of the sun symbol was not in fact identified as a problem in this case: Sámi craftspeople were using the design themselves in their products until quite recently. In the press reports cited above, craftspeople objected more to the "incomprehensible" monopoly given to Tana Gull for use of the sign ${ }^{76}$, or cultural misappropriation, than to religious concerns. As Joy indicates, the creation of handicrafts is special to Sámi because it is undertaken

71 Tana Gull and Sølvsmie AS. Availble at: https://www.tanagullogsolv.com/en (accessed: 28.06.2020).

72 Trademark Registration No. 264831. Available at: https://epalvelut.prh.fi/web/tietopalvelu/haku? appNum=T201551580\&regNum=264831 (accessed: 28.06.2020).

73 Norwegian IPO. Administrative Review. 22 January 2020.

74 Ibid. Representation of a cross (fig.).

75 This would have been difficult to obtain in any case, after the fact. To demonstrate Sámi religious beliefs about the sun god, the review referred to two websites: www.snl.no/Beaivi and www.snl.no/Sámi sk_religion. Norwegian IPO. Administrative Review. 22 January 2020.

76 Social media cooking for sun patents // Newsbeezer. 2019. Available at: https://newsbeezer. com/norwayeng/social-media-cooking-for-sun-patents-threatened-with-boycott-nrk-Sápmi/ (accessed: 28.06.2020). 
within the tradition of duodji: "the memories of the ancestors of the Sámi lives on through the art and creation of handicrafts" 77 .

Sámi objections to the trademark registration of such a symbol might in fact be quite complex. Although historically Sámi worshipped the sun god ${ }^{78}$, today most Sámi in Norway practice Christianity. As was acknowledged in the administrative review, the Sámi have experienced years of dislocation, oppression, assimilation and stigmatization. Until as late as 1980, the Norwegian government pursued a policy of assimilation, or Norwegianization, of the Sámi ${ }^{79}$. While there has been a revival of Sámi shamanistic practices in some areas, many Sámi still fear or experience discrimination in this regard ${ }^{80}$. The sun symbol could thus be understood as an identity marker linked with pre-Christian religious practice, a link to Sámi cultural cosmology and religion, as well as a part of cultural memory and heritage, and a symbol of resistance ${ }^{81}$. Even in the $17^{\text {th }}$ century, Sámi began to perceive their drums, not just as religious and/or practical objects, but as a symbol of resistance to destruction of traditional culture ${ }^{82}$. Sámi traditional craft - which may be offered for sale - is an expression of this complex relationship between traditional religious beliefs, language, and identity ${ }^{83}$. Thus, there may not be a clear distinction between "sacred" heritage and "profane" commerce.

There is another - regional - complexity to this case. In accordance with the tradition of handicraft or Duodji, Sámi tend not to mix symbols from different areas of Sápmi together. The drum on which the sun symbol was depicted is from Swedish Sápmi, and has particular significance and value for the Sámi from the area where it originated. Perhaps for these reasons, the Sámi in Norway might not publicly claim strong religious affiliations to the symbol, although they may wish to prevent misappropriation ${ }^{84}$. Perhaps this also helps to explain why Tana Gull registered the mark in Finland and Norway so far, but not in Sweden.

Whatever the situation in this case, one could imagine other cases where minority groups who have faced persecution for their beliefs, or wish to protect access to important cultural symbols they do not regard as religious, may not want to invoke arguments about "banal" commercialization of religious symbols to challenge trademark registrations. The case law on the public policy exception does not currently give much guidance on whether ideas about "blasphemy" and "banal commercialization" could be extended to cover cultural misappropriation. Further discussion is needed on this issue to avoid this provision

77 Joy F. Sámi Shamanism, Cosmology and Art as Systems of Embedded Knowledge. P. 17.

78 Lundmark B. They consider the sun to be a mother to all living creatures // Saami Pre-Christian Religion: studies on the oldest traces of religion among the Saami / eds L. Bäckman, Ä. Huldtkrantz. Stockholm: Almqvist \& Wiksell International, 1985.

79 Minde H. Assimilation of the Sámi - Implementation and Consequences // Aboriginal Policy Research Consortium International (APRCi). 2005. Available at: https://ir.lib.uwo.ca/aprci/196 (accessed: 28.06.2020). Current Norwegian policy attempts to reverse this: The Power of Culture. Norway Ministry of Culture, Meld. St. 8 (2018-2019), Report to the Storting (white paper). Available at: https://www.regjeringen.no/contentassets/9778c28ab1014b789bbb3de0e25e0d85/en-gb/pdfs/stm201820190008000engpdfs.pdf (accessed: 28.06.2020).

80 Joy $F$. The Importance of the Sun Symbol in the Restoration of Sámi Spiritual Traditions and Healing Practice.

81 Ibid.; Joy F. Sámi Shamanism, Cosmology and Art as Systems of Embedded Knowledge. P. 17.

82 Rydving $H$. The Saami drums and the religious encounter in the $17^{\text {th }}$ and $18^{\text {th }}$ centuries // Scripta Instituti Donneriani Aboensis. 1991. No. 14. P. 28-51.

83 Joy F. Sámi Shamanism, Cosmology and Art as Systems of Embedded Knowledge. P. 17. See also: Guttorm G. Traditions and Traditional Knowledge in the Sámi Culture // Being Indigenous: Perspectives on Activism, Culture, Language, and Identity / ed. by N. Greymorning. London; New York: Routledge, 2019. P. 65-75.

84 Joy F. The Importance of the Sun Symbol in the Restoration of Sámi Spiritual Traditions and Healing Practice. 
in trademark law being too narrowly interpreted and thus functioning in a discriminatory manner against such groups ${ }^{85}$.

Public domain (access to culture) arguments provided the second ground for refusing trademark registration in the sun symbol case. The follow section describes some limitations of the approach, and possible solutions.

\section{The limits of protecting the public domain}

The use of the public policy exception in trademark law provides defensive protection by preventing IP rights being exercised over a specific symbol or mark. Sámi access to the sun symbol, in the above case, was assured because the rights to use the symbol were returned to the public domain. This does not necessarily prevent cultural misappropriation or promote heritage safeguarding because anyone is allowed to use symbols in the public domain in any way they choose. Also, because trademark law is territorial, the Norwegian decision does not directly affect the registration of the same mark in Finland. The Sámi Parliament has expressed the wish to use IP protection not only defensively, to prevent unauthorized use of their culture, but also positively, as an instrument to support self-determination and respect for traditional norms and customs across Sápmi ${ }^{86}$.

To this end, community-owned trademarks have been registered to provide some positive protection. In 1982, the Nordic Saami Council registered the Sámi Duodji trademark for Sámi handicraft products in Sweden. The Sámi Duodji mark identifies Sámi handicraft products. According to the guidelines developed for its use, it should:

- communicate to buyers that the product is made by a Sámi;

- protect Sámi handicraft from being copied and from unfair competition;

- promote a continuous improvement of the quality of Sámi handicraft;

- show that Sámi handicraft is a living tradition ${ }^{87}$.

The Sámi Duodji trademark indicates the origin of a product (e. g. made by Sámi under specific conditions indicated above) but does not prevent others copying patterns and designs that have been transmitted among the Sámi for centuries. The Sámi Duodji mark also applies only to traditional handicrafts and not to modern innovations, which some craftspeople wish to sell and consider part of their heritage. An additional trademark (Sámi Made) has thus been proposed to indicate Sámi origin of a broader range of products (not only traditional duodji). This will help to ensure that these other products can be identified by consumers as new Sámi products that are based on ICH practices ${ }^{88}$.

The owners of the mark (the Nordic Saami Council) have to enforce the mark themselves, but this is expensive, and difficult outside of Sweden, the only country where the mark is registered. The trademark is managed in Finland, Russia, Norway and Sweden by different Sámi associations, so administration can be complex and has to be coordinated. Additional mechanisms could be used to help promote and enforce the mark,

85 Richardson et al. From "Oomoo" to "Oro": nostalgia labels and cultural policy on the Australian trade marks register.

86 Mattila T. Trademark protection of traditional cultural expressions of Sámi people in Finland // Nordiskt Immateriellt Rättsskydd. 2021. No. 2. Available at: https://www.nir.nu/en/argang/2021 (accessed: 08.07.2021).

87 Sámi Duodji and Sámi Made trademarks // Saami council website. Available at: https://www. saamicouncil.net/en/the-sami-duodji-certificate (accessed: 28.06.2020).

88 Mattila T. Needs of the Sámi people for intellectual property protection... 
including media engagement, additional certification labels, voluntary licenses or formal contracts $^{89}$, and codes of conduct.

Community-led coordinated regional strategies of this kind, including both defensive and positive protection, could support Sámi efforts towards self-determination and heritage safeguarding in the absence of a harmonized legal system, including sui generis intellectual property protection, for Sámi cultural expressions or traditional knowledge across Sápmi. The Nordic Sámi Convention, whose text was finalised in 2017, promises deeper Nordic cooperation on safeguarding of Sámi culture ${ }^{90}$, although it has not yet been ratified by all parties. Only Norway, and not Sweden or Finland, has ratified the International Labour Organization's Indigenous and Tribal Peoples Convention, which also makes specific provision for protecting indigenous culture ${ }^{91}$. Sámi cannot therefore fully exercise their "right to maintain, control, protect and develop their intellectual property over [their] cultural heritage" (under UNDRIP art.31), although all three countries have ratified UNDRIP.

Sui generis protection for important cultural symbols does not need to be administratively onerous or difficult to implement. In Canada, official marks (including symbols of "Aboriginal bands and native organizations") can be registered for free by Canadian public authorities. They cover all classes of goods and services, and prevent third parties from using the name or logo commercially, in perpetuity without the need for re-registration ${ }^{92}$. With state support, cultural symbols could also conceivably be registered as national symbols under Paris $6^{\text {ter93. }}$.

Taking an alternative approach, IPOs can deny trademark applications based on databases of significant cultural symbols at the point of application. In the US, for example, the Native American Tribal Insignia (NATI) database was created in $2001^{94}$ to provide information to registration authorities (the United States Patent and Trademark Office, or USPTO) at the point when applications come in. This helps in identifying symbols considered of cultural or religious significance to indigenous peoples that should be denied trademark registration. An NGO representing Native American commercial interests, the Native American Intellectual Property Enterprise Council (NAIPEC), is also represented within the USPTO to inform its intellectual property policies. There have been some prob-

89 The Pueblo of Zia successfully manage use of the Zia sun symbol in the US by third party companies under voluntary license. See: Saez C. Indigenous Knowledge Misappropriation: The Case Of The Zia Sun Symbol Explained At WIPO // Intellectual Property Watch. 2018. Available at: https://www.ip-watch. org/2018/12/11/indigenous-knowledge-misappropriation-case-zia-sun-symbol-explained-wipo (accessed: 28.06.2020); Turner S. B. The case of the Zia: looking beyond trademark law to protect sacred symbols // Student Scholarship Papers. Paper 124. 2012. Available at: http://digitalcommons.law.yale. edu/cgi/viewcontent.cgi?article=1124\&context=student_papers (accessed: 28.06.2020).

90 The English text of the Nordic Sámi Convention is available from the Sami parliament: https://www. sametinget.se/105173 (accessed: 28.06.2020).

91 Indigenous and Tribal Peoples Convention (No. 169) // International Labour Organisation. 1989. Available at: https://www.ilo.org/dyn/normlex/en/f?p=NORMLEXPUB:12100:0::NO::P12100_ILO_ CODE:C169 (accessed: 28.06.2020).

92 Udy V. The Appropriation of Aboriginal Cultural Heritage: Examining the Uses and Pitfalls of the Canadian Intellectual Property Regime // Intellectual Property Issues in Cultural Heritage (IPinCH) blog. 2015. Available at: https://www.sfu.ca/ipinch/outputs/blog/canadian-intellectual-property-regime (accessed: 28.06.2020). For a case study, see: Shrumm R. Knitting for our Lives: The Appropriation of Cowichan Sweaters by the Hudson's Bay During the 2010 Vancouver Olympics // ARTiculate. 2017. No. 2 (2). P. $120-161$.

93 State emblems and some certification marks are registered under Article $6^{\text {ter }}$ of the Paris Convention. This provides global, perpetual protection for certain emblems. South Africa has used article $6^{\text {ter }}$ to prevent misuse of Nelson Mandela's image on coins: "Mandela Wins Injunction to Prevent Use of Name and Image on Coins" // INTA Bulletin, 1 February 2005. Available at: https://www.inta.org/INTABulletin/Pages/ MandelaWinsInjunctiontoPreventUseofNameandlmageonCoins.aspx (accessed: 28.06.2020).

94 See Native American Tribal Insignia website: https://www.uspto.gov/trademark/laws-regulations/ native-american-tribal-insignia (accessed: 28.06.2020). 
lems with implementation of this system, and not all indigenous peoples wish to register their symbols, but the system could provide possible inspiration for Norway ${ }^{95}$.

\section{Conclusions}

In this paper, we have analysed a case study in which a provision in conventional intellectual property law, the public policy exception, was used to invalidate a trademark registration of a Sámi symbol in Norway. This case is of interest because intellectual property protection is often seen as a cause of cultural misappropriation, as it offers commercial enterprises the opportunity to register monopoly rights such as trademarks over signs that may be of cultural significance to communities. However, the public policy exception, which excludes registration of signs "contrary to morality or public policy", can take account of public opinion, the public interest and human rights. This offers a way to address some kinds of cultural misappropriation and mediate some of the tension between heritage safeguarding and its commercialization.

There were two main grounds for invalidating the mark in question, a Sámi sun symbol from a drum originating in Swedish Sápmi. First, use of a religious symbol as a trademark was deemed to have been "contrary to morality", because it would have been offensive to the Sámi in 2009. Second, public policy considerations and the Norwegian Constitution required ensuring continued access of Sámi craftspeople to their cultural and religious symbols. Determination of the case required a focus on the offensiveness of the sign at a specific moment, the point of time that the trademark had been registered in 2009 . However, the Norwegian IPO acknowledged the relevance of historical factors such as discrimination and religious persecution of the Sámi, and specific protections afforded to Sámi culture and language in Norwegian law.

The paper points out two main challenges relating to the use of the public policy exception in cases such as this. First, religious symbols have received disproportionate attention in case law, with a focus on preventing "blasphemous" or "banalizing" commercialization. It is not clear how this can protect the more general category of important cultural symbols which may be sacralised as "cultural heritage" by minority groups or indigenous peoples. Some groups may not be eager to represent their cultural symbols as "religious", especially in a context of historical oppression and discrimination. More research is needed to explore how the notion of blasphemy could be more broadly interpreted to include the inappropriate use of cultural symbols by third parties.

Second, simply protecting the public domain by enabling free use of cultural symbols by all does not always help indigenous peoples safeguard their heritage. Using symbols that are in the public domain, companies can free-ride on the reputation of communities and their heritage. Defensive protection against misappropriation can therefore be accompanied by other strategies including the registration of community marks, such as the Sámi Duodji and Sámi Made trademarks, although challenges remain in extracting maximum value from this approach. However, to develop a coordinated regional approach, both community action and legal or administrative support might be needed. Inspiration from other countries might be helpful in developing appropriate solutions.

\section{References}

Anemaet, Lotte. 2016. The Public Domain is Under Pressure - Why We Should Not Rely on Empirical Data When Assessing Trademark Distinctiveness. International Review of Intellectual Pro-

95 These are discussed in: Zark B. Use of Native American Tribal Names as Marks // American Indian Law Journal. 2015. No. 3 (2). Available at: https://digitalcommons.law.seattleu.edu/ailj/vol3/iss2/7 (accessed: 28.06.2020). 
perty and Competition Law: 1-33. Available at: https://ssrn.com/abstract=2749555 (accessed: 28.06.2020). DOI 10.1007/s40319-016-0459-8.

Aslaksen, Eilif Andreas. 2018. Har tatt "patent" på den Sámi ske sola. NRK Sápmi. Available at: https://www.nrk.no/Sápmi/har-tatt-_patent_-pa-den-Sámiske-sola-1.13902043 (accessed: 28.06.2020).

Blaiwais, Lauren, Miller, Scott. 2018. Offensive Trademarks: The Canadian and American Perspectives. Intellectual Property Journal 30 (2): 205-215.

Bonadio, Enrico 2015. Brands, Morality and Public Policy: Some Reflections on the Ban on Registration of Controversial Marks. Marques Intellectual Property Law Review 19: 39-61.

Bortolotto, Chiara 2020. Intangible Cultural Heritage and the Market: The Embarrassment of Heritage Alienability. Unpublished paper.

Deacon, Harriet, Smeets, Rieks. 2018. Intangible Heritage Safeguarding and Intellectual Property Protection in the context of implementing the UNESCO ICH Convention. Safeguarding Intangible Heritage, eds N. Akagawa, L. Smith: 36-53. London, Routledge.

Geiger, Christophe, Izyumenko, Elena. 2020. Shaping Intellectual Property Rights Through Human Rights Adjudication: The Example of the European Court of Human Rights. Centre for International Intellectual Property Studies (CEIPI) Research Paper No. 2020-02. Mitchell Hamline Law Review 46 (3). Available at: https://ssrn.com/abstract=3613591 or https://open.mitchellhamline.edu/mhlr/vol46/iss3/3 (accessed: 28.06.2020).

Geiger, Christophe, Pontes, Leonardo Machado. 2017. Trade mark registration, public policy, morality and fundamental rights. Centre for International Intellectual Property Studies Research Paper No. 2017-01. Available at: https://www.ip.mpg.de/en/publications/details/trade-markregistration-public-policy-morality-and-fundamental-rights.html (accessed 08.07.2021).

Guttorm, Gunvor. 2019. Traditions and Traditional Knowledge in the Sámi Culture. Being Indigenous: Perspectives on Activism, Culture, Language and Identity, ed. by Neyooxet Greymorning: 6575. London, New York, Routledge.

Joy, Francis 2018. Sámi Shamanism, Cosmology and Art as Systems of Embedded Knowledge. Doctoral Dissertation. Acta Universitatis Lapponiensis 367. Rovaniemi, The University of Lapland. Available at: http://lauda.ulapland.fi/handle/10024/63178 (accessed: 28.06.2020).

Joy, Francis. 2020. The Importance of the Sun Symbol in the Restoration of Sámi Spiritual Traditions and Healing Practice. Religions 11 (6): 270-292.

Liu, Wenqi. 2017. Protection of Religious Signs under Trademark Law: A Perspective of China's Practice. Religions 8 (11): 246-259.

Lixinski, Lucas, 2018. Intangible heritage economics and the law: listing, commodification and market alienation. Safeguarding Intangible Heritage, eds N. Akagawa, L. Smith: 54-67. London, Routledge.

Lixinski, Lucas, 2020. Commercializing Traditional Culture: Promises and Pitfalls in the Convergence of Intellectual Property Law and Cultural Heritage Law. Annali italiani del diritto d'autore, della cultura e dello spettacolo (AIDA). (Forthcoming)

Lundmark, Bo 1985. They consider the sun to be a mother to all living creatures. Saami Pre-Christian Religion: studies on the oldest traces of religion among the Saami, eds Louise Bäckman, Äke Huldtkrantz. Stockholm, Almqvist \& Wiksell International.

Manker, Ernst Mauritz. 1938. Die Lappische Zaubertrommel: Eeine Ethnologische Monographie. Vol. 1, Die Trommel als Denkmal Materieller Kultur. Acta Lapponica 1. Stockholm, Thule.

Manker, Ernst Mauritz. 1950. Die Lappische Zaubertrommel: Eine Ethnologische Monographie. Vol. 2, Die Trommel als Urkunde Geistigen Lebens. Acta Lapponica 6. Stockholm, Gebers.

Mattila, Tuomas 2018. Needs of the Sámi people for intellectual property protection from the viewpoint of copyright and trademarks - especially with regard to duodji-handicrafts and the Sámi dresses. Finland: Publications of the Ministry of Education and Culture 40. Available at: http:// julkaisut.valtioneuvosto.fi/handle/10024/161206 (accessed: 28.06.2020).

Mattila, Tuomas. 2021. Trademark protection of traditional cultural expressions of Sámi people in Finland. Nordiskt Immateriellt Rättsskydd 2. Available at: https://www.nir.nu/en/argang/2021 (accessed 08.07.2021)

Minde, Henry. 2005. Assimilation of the Sámi - Implementation and Consequences. Aboriginal Policy Research Consortium International (APRCi). Available at: https://ir.lib.uwo.ca/aprci/196 (accessed: 28.06.2020). 
Pak, Jimmy. 2011. Re-imagining the Wheel: Seeking a Feasible International Regime to Protect Indigenous Cultural Expressions Through Trademark Law. Pacific McGeorge Global Business \& Development Law Journal 24: 381-409.

Phillips, Victoria F. 2017 Beyond trademark: the Washington Redskins case and the search for dignity. Chicago-Kent Law Review 92 (2017): 1061-1086.

Reingraber, Tom. 2012. Public order and morality as grounds for refusal within trademark law: European and comparative approach. Unpublished Masters thesis. Brussel, Hogeschool-Universiteit. Available at: https://www.duo.uio.no/bitstream/handle/10852/54532/DINESH-T---Masters-Thesis. pdf?sequence=1\&isAllowed=y (accessed: 28.06.2020).

Richardson, Megan, Thomas, Julian, Klein, Jill. 2019. From "Oomoo" to "Oro": nostalgia labels and cultural policy on the Australian trade marks register. The Object and Purpose of Intellectual Property, ed. by S. Frankel: 7-29. Cheltenham, Edward Elgar Publ.

Rimmer, Matthew, 2017. Indigenous Intellectual Property: A Handbook of Contemporary Research. Research Handbooks in Intellectual Property. Cheltenham (UK), Northampton (Mass.), Edward Elgar.

Rinallo, Diego, Borghini, Stefania, Bamossy, Gary, Kozinets, Robert V. 2012. When sacred objects go $\mathrm{B} \cap \mathrm{a}(\mathrm{n}) \mathrm{d}$. Consumption and spirituality 29 (41): 29-40.

Rydving, Häkan. 1991. The Saami drums and the religious encounter in the $17^{\text {th }}$ and $18^{\text {th }}$ centuries. Scripta Instituti Donneriani Aboensis 14, 28-51. https://doi.org/10.30674/scripta.67195.

Saez, Catherine. 2018. Indigenous Knowledge Misappropriation: The Case Of The Zia Sun Symbol Explained At WIPO.Intellectual Property Watch. Available at: https://www.ip-watch. org/2018/12/11/indigenous-knowledge-misappropriation-case-zia-sun-symbol-explainedwipo (accessed: 28.06.2020).

Schovsbo, Jens, Riis, Thomas, 2018. Public Policy Limitations of Trade Mark Subject Matter - An EU Perspective. Working paper. Social Science Research Network (SSRN), May 31. Available at: https://ssrn.com/abstract=3188013 or http://dx.doi.org/10.2139/ssrn.3188013 (accessed: 28.06.2020).

Senftleben, Martin. 2013. Public Domain Preservation in EU Trademark Law - A Model for Other Regions? The Trademark Reporter 103 (4): 775-827. Available at: https://ssrn.com/abstract=2331598 (accessed: 28.06.2020).

Shrumm, Regan. 2017. Knitting for our Lives: The Appropriation of Cowichan Sweaters by the Hudson's Bay During the 2010 Vancouver Olympics. ARTiculate 2 (2): 120-161.

Silvén, Eva. 2012. Contested Sámi Heritage: Drums and sieidis on the Move, in National Museums and the Negotiation of Difficult Pasts. EuNaMus Report 8, eds Poulot, Dominique, Guiral, José María Lanzarote and Bodenstein, Felicity: 173-186. Linköping, Linköping University Electronic Press.

Solbakk, John Trygve. 1990. The Sami People. Karasjok, Norway, Sámi Institute.

Solbakk, John Trygve. 2007. Sámisk mytologi og folkemedisin [Sámi Mythology and Folk Medicine]. Tradisjonell kunnskap og opphavsrett, ed. by John Trygve Solbakk. Karasjok: Callidlagadus and Sámi kopiia (online). Available at: http://www.Sámikopiija.org/web/index. php?sladja=7\&giella1=nor (accessed: 28.06 .2020$)$.

Sommarström, Bo. 1991. The Saami Shaman's drum and the star horizons. Scripta Instituti Donneriani Aboensis 14, 136-168. https://doi.org/10.30674/scripta.67201.

Tavares, Pedro Silveira, Ziemer, Alysa Arcos, Randazza, Marc John 2019. Morality and Trademarks: The South American Approach. ip-iurisdictio 19 August 2019. Available at: https://ip-iurisdictio. org/morality-and-trademarks-the-south-american-approach (accessed: 28.06.2020).

Turner, Stephanie B. 2012. The case of the Zia: looking beyond trademark law to protect sacred symbols. Student Scholarship Papers. Paper 124. Available at: http://digitalcommons.law.yale. edu/cgi/viewcontent.cgi?article=1124\&context=student_papers (accessed: 28.06.2020).

Udy, Vanessa. 2015. The Appropriation of Aboriginal Cultural Heritage: Examining the Uses and Pitfalls of the Canadian Intellectual Property Regime. Intellectual Property Issues in Cultural Heritage (IPinCH) blog. Available at: https://www.sfu.ca/ipinch/outputs/blog/canadian-intellectual-property-regime (accessed: 28.06.2020).

Von Bomhard, Verena, Von Mühlendahl, Alexander. 2018. Concise European Trade Mark Law. The Netherlands, Wolters Kluwer, Alphen aan den Rijn.

Zark, Brian. 2015. Use of Native American Tribal Names as Marks. American Indian Law Journal 3 (2). Available at: https://digitalcommons.law.seattleu.edu/ailj/vol3/iss2/7 (accessed: 28.06.2020). 
Ziemer, Alysa Arcos, Tavares, Pedro Silveira, Randazza, Marc John. 2017. Morality and Trademarks: The South American Approach. Suffolk Transnational Law Review 40 (2): 221-278.

Received: July 2, 2020

Accepted: December 23, 2020

\title{
Этика, интеллектуальная собственность и коммерциализация культурного наследия
}

\author{
Х. Дж. Дикон
}

Для цитирования: Deacon, Harriet J. Ethics, intellectual property and commercialization of cultural heritage // Правоведение. 2020. T. 64, № 1. С. 93-111.

https://doi.org/10.21638/spbu25.2020.108

\begin{abstract}
Саамы - коренное население, проживающее в регионе Сапми, пересекающем северную Скандинавию (Норвегия, Финляндия, Швеция) и Кольский полуостров на СевероЗападе России. Статья посвящена истории символа солнца саами на барабане XVII в. из шведского города Сапми; этот символ был зарегистрирован в качестве товарного знака норвежской ювелирной компанией Tana Gull and Sølvsmie AS в 2009 г. Знак был признан недействительным в 2020 г., поскольку, по мнению Норвежского ведомства интеллектуальной собственности, регистрация религиозного символа скорее всего вызовет нарушение прав саами, чей доступ к их собственным культурным и религиозным символам должен быть защищен. Основанием для принятия решения послужило исключение из общего правила, из соображений публичной политики, а именно положение закона о товарных знаках, которое препятствует регистрации знаков, «противоречащих морали или публичной политике». Эта норма позволяет в силу закона учитывать общественное мнение, общественные интересы и права человека. Анализ этого случая используется для начала дискуссии о роли права интеллектуальной собственности в решении проблемы чрезмерной коммерциализации нематериального культурного наследия, например путем предотвращения незаконного присвоения культурных ценностей. Автор полагает, что понятие богохульства или религиозного преступления, совершаемого путем банальной коммерциализации, должно быть более широко сформулировано из соображений государственной политики, чтобы учесть незаконное присвоение элементов культуры. Утверждается, что защита общественного достояния путем предотвращения регистрации важных культурных и религиозных символов в качестве товарных знаков недостаточна для решения проблемы незаконного присвоения культурных ценностей в коммерческом контексте. Таким образом, позитивная защита посредством регистрации товарных знаков не менее важна, чем их охрана.
\end{abstract}

Ключевые слова: саами, нематериальное культурное наследие, коммерциализация, незаконное присвоение культуры, товарный знак, этика, интеллектуальная собственность.

Статья поступила в редакцию: 2 июля 2020 г. Рекомендована в печать: 23 декабря 2020 г.

Дикон Харриет Джейн - д-р философии, магистр, бакалавр (Hons), приглашенный научный сотрудник, Университет Ковентри, Великобритания, CV1 5FB, Ковентри, ул. Прайори, 1; harriet@conjunction.me.uk 